\title{
INFLUENCE OF AWARENESS, PERCEIVED IMPORTANCE, AND PERCEPTION TOWARD OTHERS ON INTENTION TO IMPLEMENT RESPONSIBLE TOURISM MARKETING
}

\author{
Ike Janita Dewi \\ ikejanitadewi@yahoo.com \\ Faculty of Economics, \\ Sanata Dharma University, Yogyakarta, Indonesia
}

\begin{abstract}
This research aims at examining influence of awareness and perceived importance on intention to implement responsible tourism marketing, moderated by perception towards other tourism stakeholders. Respondents of the research were 157 tourism Small and Medium Enterprises (SMEs) in Indonesia. Results show that while levels of awarenes and perceived importance were high, perception towards others and intention to implement responsible tourism marketing were lower. Further, awareness and perceived importance influenced positively intention to implement the concept. The influence of awareness on intention to implement was moderated by perception towards other stakeholders. This indicates that tourism industry is systemic where actions of stakeholders are highly interdependent. Individual stakeholder's decision to adopt of a certain concept/strategy depends on others' decision to also adopt it, despite the importance of such actions perceived by him/her individually.
\end{abstract}

Keywords: responsible tourism marketing, intention to implement

\section{INTRODUCTION}

This article discusses concepts and implementation of responsible tourism marketing in Indonesia. Responsible tourism marketing is derivative of sustainable tourism development in the marketing area. Marketing studies in the tourism domain has shown an extension of marketing domain which does not cover merely tangible products but in societal process and activities (Kotler and Levy, 1969). Principles, concepts, and marketing functions like segmentation, targeting, positioning, branding, and marketing mix are adopted in tourism development strategy involving a wide variety of institutions which many are non business institutions (Morrison, 2009).

On the other side, concepts and methodologies in tourism studies which have previously been dominated by recreation, economics, anthropology, and geography have witnessed an increased emphasis in business administration and management. Among variety of business perspectives related with tourism development, marketing is perhaps the most active perspective contributing to the discourse of tourism studies (Li and Petrick, 2008). It shows that marketing has become an important domain in tourism studies.

Studies on tourism marketing in Indonesia are significant to conduct due to the importance of the sector. Number of foreign and domestic tourists visiting tourism destinations has increased yearly and reached 15.81 million foreign tourists and 303.5 millions of travels by domestic tourists in 2018 (Kementerian Pariwisata, 2019). Indonesia tourism has experienced a steady growth and was ranked as the $3^{\text {rd }}$ highest in Asia and the $9^{\text {th }}$ highest in the world with a growth rate of $25.68 \%$ (World Travel and Tourism Council, 2018).

In terms of contribution to the coutry's Gross Domestic Product, in 2018 tourism sector contributed as much as $5.25 \%$ to the national GDP. The growth rate of foreign exchange receipt from tourism sector has recorded a $13 \%$ growth, which is the highest amongst traditional foreign exhange sources of oil and gas, coals, and crude palm oil. In 2018, tourism sector generated foreign exhange of IDR224 trillions (or USD 16 billion).

As depicted in Table 1, tourism growth in Indonesia has shown impressive performance in terms of number of tourists (both foreign and domestic), contribution to GDP, and employment. However, critics have been levelled at the indicators of performance since they are biased towards the economic benefits. The negative impacts or tourism on environment and socio-cultural aspects have been overlooked. 
TABLE 1

Indonesian Tourism Performance (2015-2018)

\begin{tabular}{lcccc}
\hline & 2015 & 2016 & 2017 & 2018 \\
\hline Contribution to GDP & $4.25 \%$ & $4.13 \%$ & $5 \%$ & $5.25 \%$ \\
Foreign Exchange Receipts (IDR trillion) & 175.71 & 176.23 & 202.13 & 224 \\
Number of employment (million) & 10.36 & 12.28 & 12.6 & 12.7 \\
Competitiveness Index (WEF) rank & 50 & n.a & 42 & n.a \\
Number of Foreign Tourists (million) & 10.41 & 12.02 & 14.04 & 15.81 \\
Number of Domestic Tourists & 256.42 & 264.33 & 270.82 & 303.5 \\
(number of travels, million) & & & &
\end{tabular}

Source: Ministry of Tourism Republic of Indonesia (2019).

The tourism sector in Indonesia is (supposedly) developed based on the four-track strategies, that is, 'pro poor, pro job, pro growth, and pro environment.' This represents the adoption of sustainble tourism development, which balance out the three roles of tourism development in terms of economic contribution, natural resources, and sosial/cultural values protection. In Indonesian context, tourism development aims to contribute to the economy with a special purpose of poverty alleviation. This brings the implications of the emphasis on community-based tourism development. The roles of small and medium enterprises, community, and local people are mainstreamed and strengthened in the development.

While tourism's economic contribution is quite straightforward, the implication of the economic growth on social/cultural values and natural resources protection is usually put aside. Since Small and Medium Enterprises (SMEs) and local society are expected to become the main agents of the tourism development in Indonesia, there is an urgent need to conduct a research on the current status of the adoption of sustainable tourism development by SMEs in Indonesia.

The purposes of this research are twofold. Firstly, this research examines level of awareness, perceived importance, perception towards others, and intention to implement Responsible Tourism Marketing amongst tourism SMEs in Indonesia. A descriptive analysis of the findings indicate the general status with regards to those variables. The second purpose of this study is to examine influence of awareness and perceived importance on intention to implement responsible tourism marketing, moderated by perception towards other tourism stakeholders.

\section{LITERATURE REVIEW AND HYPOTHESES FORMULATION}

\section{A. Sustainable Tourism Development and Responsible Tourism Marketing}

World Tourism Organization formulates the Global Code of Ethics for Tourism which emphasizes efforts to apply the sustainable tourism development to benefit the entire society. Sustainable tourism development has 12 aims as follows: (http://www.docstoc.com/docs/11638050/UNWTO-12-Aims-for-Sustainable-Tourism): (1) Economic viability, (2) Local prosperity, (3) Employment quality, (4) Social equity, (5) Visitor fulfillment, (6) Local control, (7) Community wellbeing, (8) Cultural richness, (9) Physical integrity, (10) Biological diversity, (11) Resource efficiency, and (12) Environmental purity.

Sustainable tourism development is basically sustainable development achieved through tourism. Sustainable development is an economic development which takes a long term perspective. Such a perspective balances economic benefits against environment and social impacts. Just like the sustainable development which assumes sustainable economic growth, sustainable tourism development assumes sustainable tourism growth.

Sustainable tourism development is reached when environmental, community and economic values are balanced through collaboration and compromise to achieve a level and style of tourism that (Wray, 2010; WTO, 2004):

(1) protects and enhances the natural and built environment upon which the tourism industry is based;

(2) is consistent with community values both now and over the long term, and contributes to community development and well-being;

(3) is appropriately developed and marketed so that it is distinctive, competitive and synergetic, and with the flexibility to respond to market changes now and in the future;

(4) increases the contribution of tourism to the economy and promotes long-term industry viability; and

(5) increases destination appeal, delivers on brand promise, increases repeat visitation and enhances the reputation of the destination resulting in increased yield from tourism. 
Responsible tourism marketing in tourism business is the derivative of sustainable tourism development, that is, on the aspects related with tourism marketing. Basically, responsible tourism marketing is parallel with green marketing concept (Ottman, 1993) and environmental marketing (Coddington, 1993). These two concepts are relevant to include in the development of responsible tourism marketing. Nevertheless, sustainable tourism development extends as well specifies the concepts in the area of tourism development.

Responsible tourism marketing adds sustainable principles to the standard mix of marketing decisionmaking variables. However, the variable is unique and special since it is omnipresent, serving as a backdrop against which all strategic decisions are made (Coddington, 1993). The entire decisions in tourism marketing including product development, promotion, and advertising, take sustainability principles into account.

The implementation of responsible marketing serves at least two objectives (Ottman, 1993) that is, (1) developing product which balance consumers' need for quality, affordable price, and convenience with environmental compatibility, that is, a minimal impact on the environment and (2) projecting an image of high quality, including environmental sensitivity, relating to both a product's attributes and its manufacturer's track record for environmental compliance.

On the other hand, marketing discipline will help achieve more sustainable forms of tourism (Swarbrooke, 1999). Marketing can become a powerful force that influences everyone because it always seeks to understand customers in terms of their motivations and determinants. Marketing research also helps to describe consumer attitudes towards sustainable tourism which in turns serve as a basis to develop market-led tourism products.

On the demand side, sustainability issues have also played more roles in tourists' motivation to visit a destination (Hassan, 2000). Generally, green consumer trend has strengthened. Tourists will select and evaluate destinations base on sustainability indicators. Generally, the environmentally oriented segments are growing at a very high rate. For example, a survey conducted on 9,000 North American, European, Chinese, and Japanese showed that even in time of financial crisis, more consumers looked for more green products in 2008, compared to those in 2007. As many as $34 \%$ of European societies (with an increase of $2 \%$ compared to 2007) said that they would systematically look for green products. The study also showed that $32 \%$ of 1.040 North American respondents, in January 2008, stated that they would look for and buy green products (http://businessweek.com).

Other research also indicates, that besides seeking a more meaningful experience at a destination, tourists are beginning to concern the impacts that their visit has on the host destination (Bachleitner and Zins, 1999 as cited in Spenceley, 2010). Spenceley (2010) further points out that, according to research by the Association of British Travel Agents, $87 \%$ of tourists felt it to be important that their holiday did not damage the environment while $76 \%$ of respondents said that tourism should benefit those in the destination through jobs and business opportunities.

In a wide variety of destinations of choices, a destination has to remain competitive and develop sustainable tourism products to attract these segments (http://www.greentourism.org.uk and http://www.sustainabletourism.travel). The roles of tourism product suppliers in adopting and implementing the principles of responsible tourism marketing therefore are imperative. This present research examines the relationships amongst awareness of the Responsible Tourism Marketing concept, perceived importance of the concept in building tourism competitive advantage, perception towards other stakeholders with regards to adoption and implementation of the concept, and intention to implement it.

\section{B. Hypotheses Formulation}

The present research examines awareness or consumers' ability to recognise and recall an object in the midst of other concepts, because awareness is the first step for ones to build attitudes and purchase intention. Aaker (1996) and Keller (1993) stated that awareness plays important role in consumers' decision making for three main reasons. Firstly, awareness affects consumer decision making by influencing the formation and strength of association of the concept in consumers' minds. Second, awareness plays an important roles whenever consumers consider several alternatives. Thirdly, awareness can affect choice. Therefore, awareness of tourism SMEs of the Responsible Tourism Marketing is a predictor to their intention to implement it. Based on these lines of arguments, the research formulates Hypothesis 1 as follows.

\section{$H_{1}$ : Awareness influences positively intention to implement}

While awareness leads to intention to implement, there is another important predictor of perceived importance. Perceived importance shows the level of personal opinions of the importance of the issue of responsible tourism marketing. Parallel with the role of involvement in influencing intention to purchase (Solomon, 1994, p. 83), perceived importance will determine the consumer's motivation to process product-related information (Celsi and Olson, 1988). Therefore perceived importance of responsible tourism marketing in building Indonesian tourism competitiveness will provide motivation for tourism suppliers to implement it. Failure to perceive the importance of concept will not lead to intention to implement it. Therefore, Hypothesis 2 states: 


\section{$\mathrm{H}_{2}$ : Perceived importance influences positively intention to implement}

On the basis of theory of reasoned action (Ajzen and Fishbein, 1980; Fishbein and Ajzen, 1975), one's behavior is affected by the power of other people. Many of our behaviors are not determined in a vacuum. Since tourism industry involves a highly connected inter-sectoral system (Mill and Morrison, 2002), the behavior of tourim stakeholders are likely to be influenced by their perception towards other stakeholders. Rarely does individual tourism SME decides to take an action without a certain confidence that the whole tourism system will support him/her. Therefore, while awareness and perceived importance direct intention to implement, the influences of these variables on intention to implement will be strengthened or weakened by perceptions towards others. From a management perspective, Yaman and Gurel (2006) stated that tourism decision-makers are more likely to adopt ethical management practices where they believed such actions to be effective. Based on this reasoning, Hypothesis 3 is stated as follows.

$\mathrm{H}_{3}$ : The strength of links between awareness and intention to implement and between perceived importance and intention to implement are influenced by perceptions towards others.

The relationships amongst variables as stated in Hypotheses 1-3 are depicted in Figure 1 below.

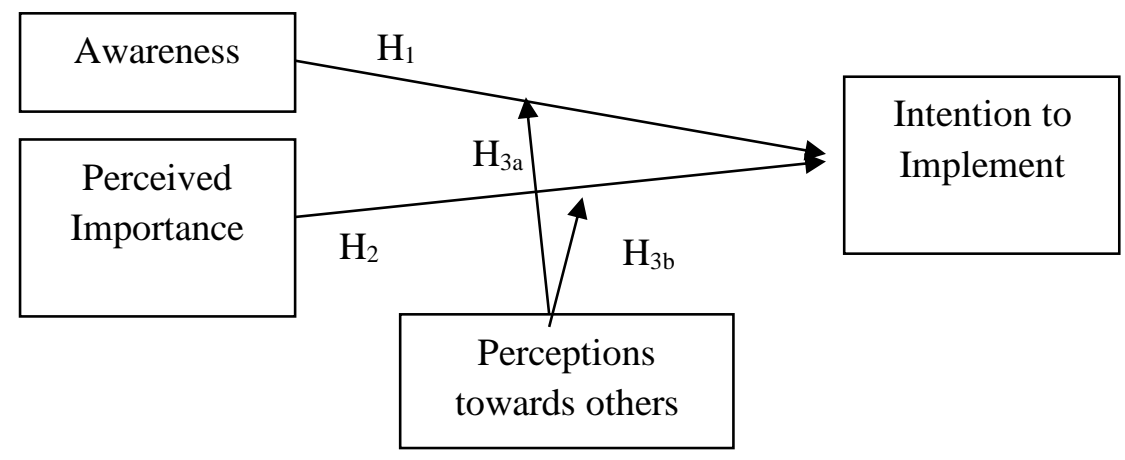

Figure1: Conceptual Model

\section{METHODS}

This research is a quantitative research. The research is designed as a formal study (by the degree to which the research question has been crystallized) and as a causal study (by purposes of the research) and (Cooper and Schindler, 2009). We employ purposive sampling and multiple regression analysis. The research SPSS was used to analyze the data. Validity and reliability testing were conducted before the hypothesis testing.

The content validity of the questionnaire was assessed through a pilot testing with 5 respondents which met the sample criteria. Some changes were made in order to clarify the instructions and questions according to their feedback and comments. The construct validity was assessed through total-item correlation. The item of the construct is valid if corrected total-item correlation $>0.2$ (Garret 1960). To asses the reliability of the instrument, the items' consistency were tested using cronbach's alpha. A value of 0.6 or less generally indicates unsatisfactory internal consistency reliability (Malhotra 2004). Prior to conducting the multiple regression analysis with interaction effects, tests of the regression assumptions (multicollinearity, homoscedasticity, and normality of residuals) were performed.

Multiple regression analyses were performed to assess the relative influence of the independent variables (awareness, perceived importance, and perception towards others) on the dependent variable (intention to implement).

The regression equations of the relationships are as follows.

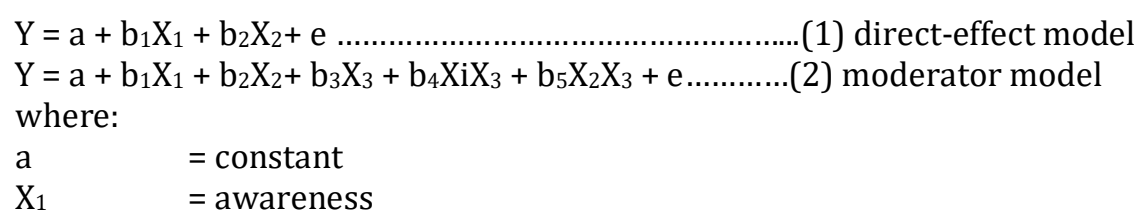




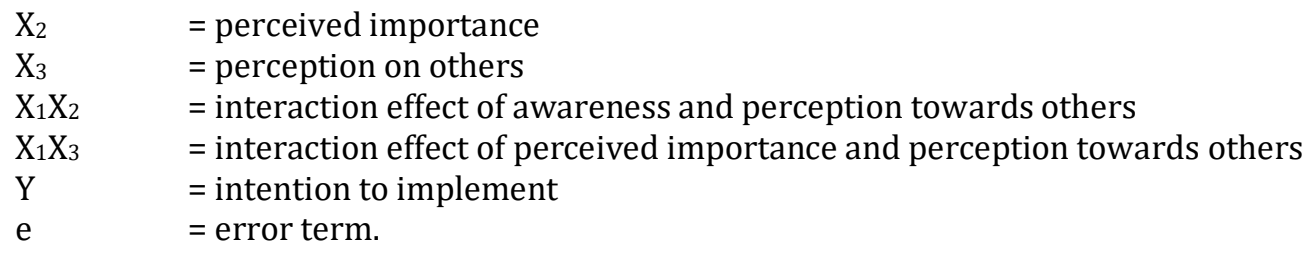

The research was conducted in Yogyakarta on 157 respondents. Samples were taken using purposive sampling. While the samples were pretty limited, they were representatives of the general population of SMEs in Indonesian tourism industry. In Indonesia, SMEs are defined as companies with assets (other than land and building) less than USD 1 million, employees less than 300 people, and total sales of less than USD 100 thousands/year. Also, the companies are not subsidiary of bigger or multinational companies (http://infoukm.wordpress.com/tag/kriteria-ukm/). The respondents were owners or managers of tourism SMEs and community tourism which included hotel owners, managers of tourism villages, tour and travel company owners, restaurants, and other services in Central Java and Yogyakarta Provinces.

The main part of the questionnaire in the survey consisted of 10 closed-ended questions. The questionnaire was designed to inquire about tourism SMEs' awareness and intention to implement responsible tourism marketing strategies. There were 4 variables examined, that is, "awareness", "perception towards others", "perceived importance", and "intention to implement".

Awareness was measured with two items: (1) understand the concept, and (2) able to tell about the concept. Variable of "perceived importance" was measured using three questions: (1) responsible tourism marketing will enhance Indonesian tourism competitiveness, (2) responsible tourism marketing ethos must be adopted by the entire tourism stakeholders, and (3) Indonesian tourism must be developed based on responsible tourism marketing ethos. Variable "perception towards other stakeholders was measured with three questions: (1) foreign tourists have appreciated environment and local society of the tourism destination, (2) domestic tourists have appreciated environment and local society of the tourism destination, (3) tourism stakeholders in Indonesia have adopted responsible tourism marketing strategies. Whereas, variable "intention to implement" included two questions of (1) intention to implement and (2) intention to promote. Responses were coded using Likert Scale (Strongly Agree-Agree-Neutral-Disagree-Strongly Disagree). The score ranges from Strongly Agree (5) to Strongly Disagree (1).

Based on validity and reliability test, all items passed the test, with cronbach alpha score of higher than 0.6 and corrected item-to-total correlation of higher than 0.2 . Therefore, we could keep all the items for further analyses. Tests on classical assumptions were also conducted prior to interpretation of results of regression analyses.

\section{RESULTS AND DISCUSSION}

Table 2 and 3 depict results of the survey. The respondents were 157 owners of tourism SMEs located in Yogyakarta and Central Java, Indonesia. The SME status of their companies were confirmed in terms of yearly total sales and number of employees. The companies vary from gift shops (21.7\%), tourist tranportation (20.4\%), tour and travel $(17.8 \%)$, tourist recreation area $(5.1 \%)$, restaurant $(9.6 \%)$, guide $(9.6 \%)$, hotel $(7.6 \%)$, and others (8.3\%). The rest of the demographic profile of respondents are presented in Table 2.

The mean values and standard deviation for each of the item are shown in Table 3. Generally, tourism SMEs were aware of responsible marketing concept (Mean value $=3,63$ ). They also perceived that the concept is important in building Indonesian tourism competitiveness (mean value $=3,93$ ). However, their perception towards others showed lower mean value of 3.41. Likewise, mean value of intention to implement was lower of 3.41. Other interesting results to highlight are that respondents perceived that foreign tourists value responsible tourism higher than domestic tourists did (mean value $=4.05$ vs 3.25). The rest of the descriptives are depicted in Table 3. 
Table 2

Profile of Respondents

\begin{tabular}{|c|c|c|}
\hline Descriptor & $\mathrm{N}$ & $\%$ \\
\hline \multicolumn{3}{|l|}{ Gender } \\
\hline Men & 98 & $62.4 \%$ \\
\hline Women & 59 & $37.6 \%$ \\
\hline \multicolumn{3}{|l|}{ Age } \\
\hline$\leq 30$ & 23 & $14.6 \%$ \\
\hline $31-40$ & 31 & $19.7 \%$ \\
\hline $41-50$ & 70 & $44.6 \%$ \\
\hline$>50$ & 33 & $21.0 \%$ \\
\hline \multicolumn{3}{|l|}{ Marital status } \\
\hline Single & 31 & $19.7 \%$ \\
\hline Married & 126 & $80.3 \%$ \\
\hline \multicolumn{3}{|l|}{ Residence } \\
\hline Yogyakarta & 101 & $64.3 \%$ \\
\hline Central Java & 56 & $35.7 \%$ \\
\hline \multicolumn{3}{|l|}{ Education } \\
\hline High school & 15 & $9.6 \%$ \\
\hline Diploma & 57 & $36.3 \%$ \\
\hline Bachelor & 76 & $48.4 \%$ \\
\hline Master & 4 & $2.5 \%$ \\
\hline Others & 5 & $3.2 \%$ \\
\hline \multicolumn{3}{|l|}{ Job/Company type } \\
\hline Hotel & 12 & $7.6 \%$ \\
\hline Restaurant & 15 & $9.6 \%$ \\
\hline Tour and Travel & 28 & $17.8 \%$ \\
\hline Gift Shop & 34 & $21.7 \%$ \\
\hline Tourist transportation & 32 & $20.4 \%$ \\
\hline Tourist recreation area & 8 & $5.1 \%$ \\
\hline Guide & 15 & $9.6 \%$ \\
\hline Others & 13 & $8.3 \%$ \\
\hline \multicolumn{3}{|l|}{ Company sales/year } \\
\hline$<$ IDR100 mill & 87 & $55.4 \%$ \\
\hline IDR101 mill - IDR250 mill & 32 & $20.4 \%$ \\
\hline IDR251 mill - IDR400 mill & 24 & $15.3 \%$ \\
\hline IDR401 mill - IDR550 mill & 12 & $7.6 \%$ \\
\hline > IDR 550 mill & 2 & $1.3 \%$ \\
\hline \multicolumn{3}{|c|}{ Number of employees (full-time equivalent) } \\
\hline$>5$ people & 75 & $47.8 \%$ \\
\hline 5-20 people & 11 & $7.0 \%$ \\
\hline 21-50 people & 21 & $13.4 \%$ \\
\hline 51-100 people & 47 & $29.9 \%$ \\
\hline$>100$ people & 2 & $1.3 \%$ \\
\hline
\end{tabular}


Results of regression analysis are as follows:

$$
\begin{gathered}
\text { Model } 1 \text { (direct effect model) }: \\
\mathrm{Y}=0.70+0.563 \mathrm{X}_{1}{ }^{* * *}+0.159 \mathrm{X}_{2}{ }^{* *} \\
\text { Model } 2 \text { (moderator model) } \quad: \\
\mathrm{Y}=-0.574+0.214 \mathrm{X}_{1}+0.826 \mathrm{X}_{2}^{* *}+0.455 \mathrm{X}_{3}^{* * *}+0.093 \mathrm{X}_{1} \mathrm{X}_{3}-0.202 \mathrm{X}_{2} \mathrm{X}_{3}{ }^{* *} \\
\text { Note: }{ }^{* * *} \text { ) significant at } \mathrm{p}<0.01 \\
* * \text { ) significant at } \mathrm{p}<0.05
\end{gathered}
$$

The regression analyses created two regression equations, that is, first model of main effect regression equation (without moderator), and second equation of moderator model. Based on the first equation, results show that Hypothesis 1 and 2 were supported, that is, awareness $\left(\mathrm{X}_{1}\right)$ influences positively intention to implement $(\mathrm{p}<0.01)$ and perceived importance $\left(\mathrm{X}_{2}\right)$ influences positively intention to implement $(\mathrm{p}<0.05)$. Regression coefficient for awareness is bigger than that of perceived importance showing the bigger influence of awareness on intention to implement compared to that of perceived importance.

In testing moderator effect, Baron and Kenny (1986) advised that significant moderating effect is shown by significant main effect of the moderating variable and significant interaction effects of the predictor $\mathrm{x}$ moderator. Result of equation 2 shows that main effect of the moderating variable of perception towards others is significant $(p<0.05)$. The interaction effect between perceived importance and perception towards others is also significant $(p<0.01)$. However, the interaction effect between awareness and perception towards others is insignificant. The second model also shows insignificant main effect of predictor of awareness, but, this is not directly relevant conceptually to testing the moderator hypothesis (Baron and Kenny, 1986).

The significant result of the moderator hypothesis of $\mathrm{H}_{3 b}$ shows that the influence of perceived importance of responsible tourism marketing on intention to implement is weakened by perception towards others. This means that while tourism SMEs perceived that responsible tourism marketing is important, they would implement the concept only if they perceived that other stakeholders also placed high value on it. This once again points out the systemic nature of tourism industry where interdependencies amongst stakeholders are high.

However, the interaction effect between awareness and perceived importance is not significant. Thus, Hyptohesis $3 a$ is not supported. Perception towards others does not interfere in the influence of awareness on intention to implement. This supports Keller's theory that awareness plays an important role for consumers in considering several alternatives and in making a choice, even though others do not make the same choice. This also supports the need for creating change in responsible tourism management through social marketing to build awareness and positive attitudes of stakeholders towards it (George and Frey, 2010).

Table 3

Awareness, Perceived Importance, Perception on Others, and Intention to Implement Responsible Tourism Marketing Strategies: Descriptive Statistics

\begin{tabular}{lccccc}
\hline & $\mathrm{N}$ & Minimum & Maximum & Mean & $\begin{array}{c}\text { Std. } \\
\text { Deviation }\end{array}$ \\
\hline AWARE1 & 157 & 2.00 & 5.00 & 3.8217 & .81259 \\
AWARE2 & 157 & 2.00 & 5.00 & 3.4331 & .63320 \\
IMPORT1 & 157 & 2.00 & 5.00 & 3.8280 & .69040 \\
IMPORT2 & 157 & 2.00 & 5.00 & 3.9236 & .77245 \\
IMPORT3 & 157 & 2.00 & 5.00 & 4.0446 & .82698 \\
OTHER1 & 157 & 2.00 & 5.00 & 3.9745 & .85447 \\
OTHER2 & 157 & 1.00 & 5.00 & 3.1975 & 1.05271 \\
OTHER3 & 157 & 1.00 & 5.00 & 3.0573 & .85666 \\
INTENT1 & 157 & 2.00 & 5.00 & 3.4904 & .73045 \\
INTENT2 & 157 & 2.00 & 5.00 & 3.3248 & .67193 \\
Average AWARENESS & 157 & 2.50 & 5.00 & 3.6274 & .58809 \\
Average IMPORTANT & 157 & 2.33 & 5.00 & 3.9318 & .57734 \\
Average OTHERS & 157 & 1.67 & 5.00 & 3.4097 & .60831 \\
Average INTENTION & 157 & 2.00 & 5.00 & 3.4076 & .56846 \\
Valid N (listwise) & 157 & & & & \\
\hline
\end{tabular}

Source: Primary data; processed 


\section{CONCLUSION AND IMPLICATIONS}

Results of the survey show that the main challenges for responsible tourism marketing in Indonesia lie on the implementation levels. Indonesian tourism SMEs have in fact understood the concepts and recognized the importance of it. However, they were reluctant to implement it since they were quite unsure that their consumers, that is, foreign and let alone domestic tourists, have adequate appreciation towards it. Appreciation of tourists towards responsible tourism marketing can manifest in the role of "responsible attributes" in their selection of destinations/tourism objects to visit, willingness to pay premium price for responsible tourism products, or loyalty (repeat visits) towards responsible tourism destinations. Tourism industry in Indonesia seems to perceive that tourists have not yet valued such responsible tourism attributes.

Tourism SMEs in Indonesia seem to be pragmatical in their consideration whether to apply responsible tourism marketing. If consumers were perceived not yet appreciating the concept, they would not implement it. Given this condition, efforts to promote the implementation of responsible tourism marketing strategies in Indonesia should emphasize at least two things, that is, (1) by highlighting its tangible (read: economic) benefits and (2) by influencing the consumers to "demand" the tourism services suppliers to apply responsible tourism marketing.

\section{Implications for Policy Formulation and Further Studies}

This research should be followed up with government regulation and policy to mainstream the principles of responsible tourism marketing into the national tourism development strategies. The good news is that the formulation of the National Tourism Strategic Plan shows that such principles have been adopted and stated explicitly. The Strategic Plan which is entitled Sustainable Tourism Strategic Plans of Republic Indonesia, which to be implemented for the period of 2010-2025. The tourism marketing domain in the Strategic Plan has also adopted the principles of responsible tourism marketing quite consistently. However, such Strategic Plans should be manifested as Government Regulation to legally bind other sectors (other than the tourism sector) in consistent implementation of the plans. Further, in Indonesia, adoption and implementation of strategic plans by the entire regional (at the provincial and district levels) tourism agencies will need the development of (what so called) Norms, Standards, Procedures, and Criteria. This document will provide detailed technical guidelines for the implementation of the Sustainable Tourism Strategic Plans.

This research should be also followed-up with other research to elaborate on the points proposed in this research to start the implementation of responsible tourism marketing. If tourism SMEs have basically understood the concepts of responsible tourism marketing, the challenge is to provide technical guides to implement it. The necessary technical guides are on tourism product development, promotion, market development, and tourism education guidelines. The development of such technical guidelines should refer to best practices in other tourism destinations as benchmarking efforts.

Further, other research should be conducted to analyze levels of awareness, perceived importance, and perceptions towards others of tourism SMEs in other destinations in Indonesia on responsible tourism marketing. Results on the present research which indicated high awareness of tourism SMEs on the concept might be biased by the fact that the locus of the research is in Yogyakarta. Yogyakarta is considered an advanced tourism destination in Indonesia with well-educated stakeholders. Therefore, findings of this research might not represent awareness of Indonesian tourism SMEs in general. Further research should be conducted to gain more accurate data to better formulate implementation strategy of responsible tourism marketing in Indonesia.

Further research should develop in particular standards and measures for responsible tourism marketing strategies and actions. Such measures will help assess the status of awareness and adoption by tourism SMEs or general stakeholders in Indonesia, as well as provide clear guidelines for implementation for a broder basis of stakeholders. 


\section{REFERENCES}

Aaker, David. A. (1996). Building Strong Brands. New York: Free Press.

Ajzen, I. and Fishbein, M. (1980). Understanding Attitudes and Predicting Behavior. New Jersey: Prenctice Hall.

Baron, Reuben M and Kenny, David A.. (1986). "The Moderator-Mediator Variable Distinction in Social Psychological Research: Conceptual, Strategic, and Statistical Considerations". Journal of Personality and Social Psychology, 51 (6), 1173-1182.

Celsi, R. and Olson, J.C. (1988). "The Role of Involvement in Attention and Comprehension Processes." Journal of Consumer Research, 15 (September), 210-224.

Coddington, Walter. (1993). Environmental Marketing: Positive Strategies for Reaching the Green Consumer. New York: McGraw-Hill.

Cooper, D.S. and Schindler, P.S.. (2009). Business Research Methods. $11^{\text {th }}$ Edition. New York: McGraw Hill.

Departemen Kebudayaan dan Pariwisata Republik Indonesia. (2009). Panduan Pemasaran Pariwisata yang Bertanggungjawab (Responsible Tourism Marketing). Jakarta: Department of Culture and Tourism.

Fishbein, Martin. \& Icek Azjen (1975). Belief, attitude, intention and behavior: an introduction to theory and research. MA: Addison Wesley.

Frause, Bob and Colehour, Julie A.. (1994). The Environmental Marketing Imperative: Strategies for Transforming Environment Commitment into A Competitive Advantage. Chicago: Probus Publishing Company.

Garret, H. E. (1960). Statistics in Psychology and Education. $5^{\text {th }}$ Edition. New York: Longman.

Hassan, Salah S. (2000). "Determinants of Market Competitiveness in an Environmentally Sustainable Tourism Industry". Journal of Travel Research, 38 (February), 239-245.

Kotler, Philip dan Keller, Kevin Lane (2016). Marketing Management. 15 ${ }^{\text {th }}$ Edition. New Jersey: Pearson Education.

Kotler, Phillip dan Levy, Sidney J. (1969). "Broadening the Concept of Marketing”. Journal of Marketing, 33 (January), 10-15.

Keller, Kevin Lane (1993). Strategic Brand Management: Building, Measuring, and Managing Brand Equity. $2^{\text {nd }}$ Edition. New Jersey: Pearson Education.

Li, Xiang (Robert) and Petrick, James F. (2008). “Tourism Marketing in an Era of Paradigm Shift.” Journal of Travel Research, 48, 235-244.

Mill, Robert Christie and Morrison, Alastair M.. (2002). The Tourism System. $6^{\text {th }}$ Edition. Sidney: Kendall Hunt Publishing Company.

Morrison, Alastair M. (2010). Hospitality \& Travel Marketing. $4^{\text {th }}$ Edition. New York: Delmar Cengage Learning.

Ottman, Jacquelyn. (1992). Green Marketing: Challenges \& Opportunities for the New Marketing Age. Lincolnwood: NTC Publishing Group.

Peirce, Mike and Madden, Katherine, (2009). Marketing and Sustainable Development, Cambridge: World Business Council for Sustainable Development, HRH Prince of Wales Business \& the Environment Programme, and University of Cambridge Programme for Industry.

Putri, Ananda Widhia (October 19, 2017), "Menjadikan Pariwisata sebagai Core Business Indonesia", https://swa.co.id/wicf/news/menjadikan-pariwisata-sebagai-corebusiness-indonesia [Acessed: 2019, January 2]

R. George dan Frey N. (2010). "Creating Change in Responsible Tourism Management through Social Marketing. South African Journal of Business Management, 41 (1), pp. 11-23. 
Spenceley, Anna. (2010). Responsible Tourism: Critical Issues for Conservation and Development. London: Earthscan.

Swarbrooke, John. (1999). Sustainable Tourism Management. Cambridge: CABI Publishing.

World Tourism Organization. (2004). Indicators of Sustainable Development for Tourism Destinations, France: UNWTO [http://www.unwto.org.]

Wray, Meredith, Dredge, Dianne, Cox, Carmen, Buultjens, Jeremy, Hollick, Mary, Lee, Diane, Pearlman, Michael, \& Lacroix, Carol. (2010). Sustainable Regional Tourism Destinations: Best Practice For Management, Development and Marketing. Goldcoast: CRC for Sustainable Tourism Pty Ltd.

Yaman, H. and Gurel, E. 2006. "Ethical Ideologies of Tourism Marketers”. Annals of Tourism Research, Vol. 33 (No. 2), 470-489.

United Nations Environment Program and World Tourism Organization (2005), Making Tourism More Sustainable: A Guide of Policy Makers. France: UNEP and WTO [http://www.unep.fr/shared/publications/pdf/DTIx0592xPA-TourismPolicyEN.pdf] [Acessed: 2019, July 2]

“Laporan Akuntabilitas Kinerja Kementerian Pariwisata 2018” (2019, June 19), Available: www.kemenpar.go.id, [Accessed: 2019, July 2].

“Expert Group Meeting for the Global Sustainable Development Report Tourism sustainability" (2013, October 23) Available: https://sustainabledevelopment.un.org/content/documents/4016Knezevic EGM\%20Dubrovnik.pdf [Acessed 2019, July 2]

"Klasifikasi UKM" (2008, Agustus 29), Available: http://infoukm.wordpress.com/tag/kriteria-ukm/ [Acessed: 2018, February 17]

“One in Five Jobs of All New Jobs Created Globally in 2017 are attributable to Travel \& Tourism (2018, March 220) Available: http://www.wttc.org/ [Accessed: 2019, June 3] 